\title{
LEAVING THE SIMPSON DESERT
}

\author{
Luise Hercus
}

\section{INTRODUCTION}

Whenever - as appears to be common these days - people claim they are the first to cross the Simpson Desert from south to north or west to east, walking or running, in winter or summer, they forget that others were there before them: the Simpson Desert was home for generations of Aboriginal people. The southern Simpson Desert was the territory of the Wangkangurru. Their only permanent source of water was what they called mikiri. These were small soaks: they were described for the first time by David Lindsay in the journal of

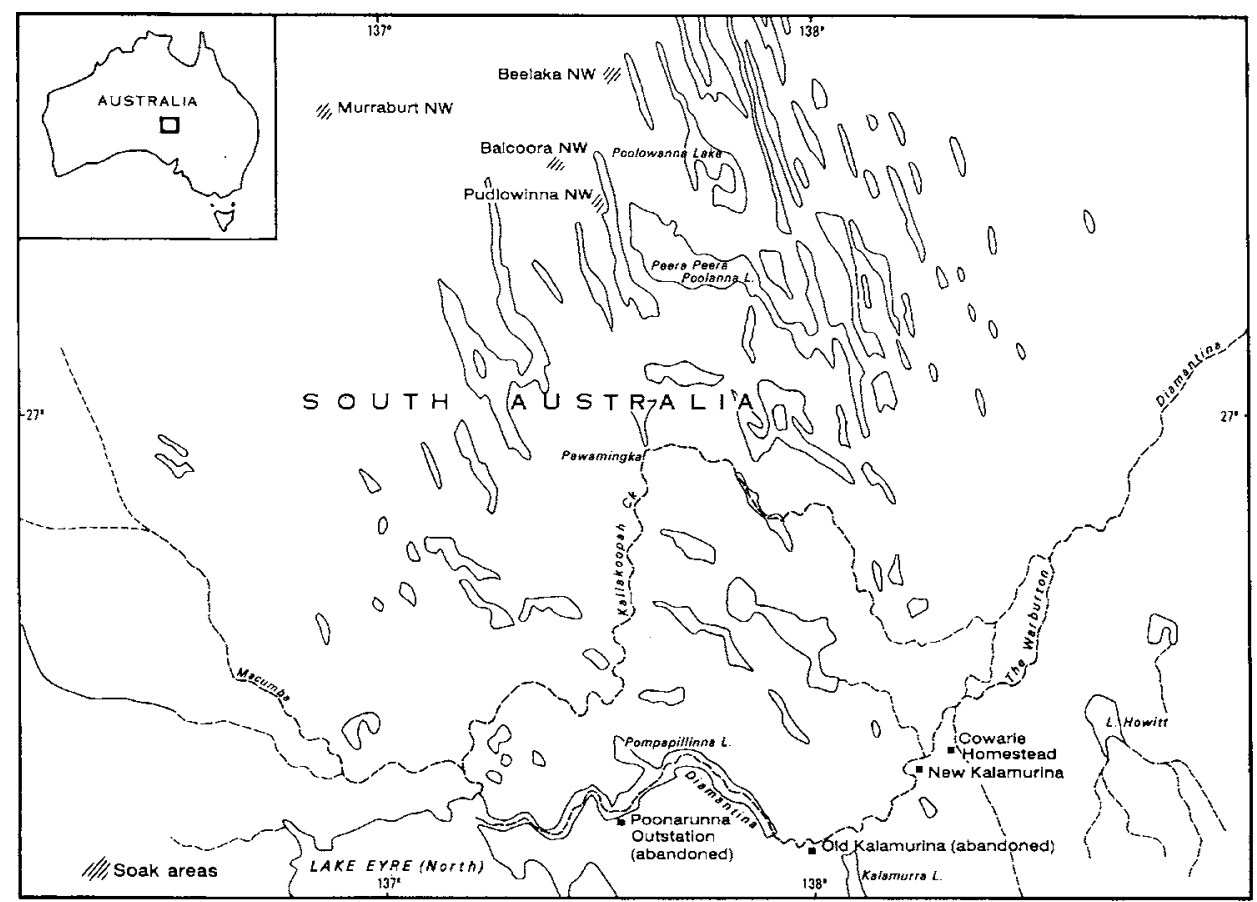

The Simpson Desert Area

his expedition into the Simpson Desert in 1886 . He visited nine of these soaks with the help of a Wangkangurru man named 'Paddy'. Thanks to brilliant navigation by Dennis Bartell, who had studied Lindsay's journal and worked out distances in camel-time, the prehistorian

Luise Hercus is Reader in Sanskrit at the Australian National University. She has been studying Aboriginal languages and oral traditions for over twenty years, particularly in areas where there are only a few speakers left. 


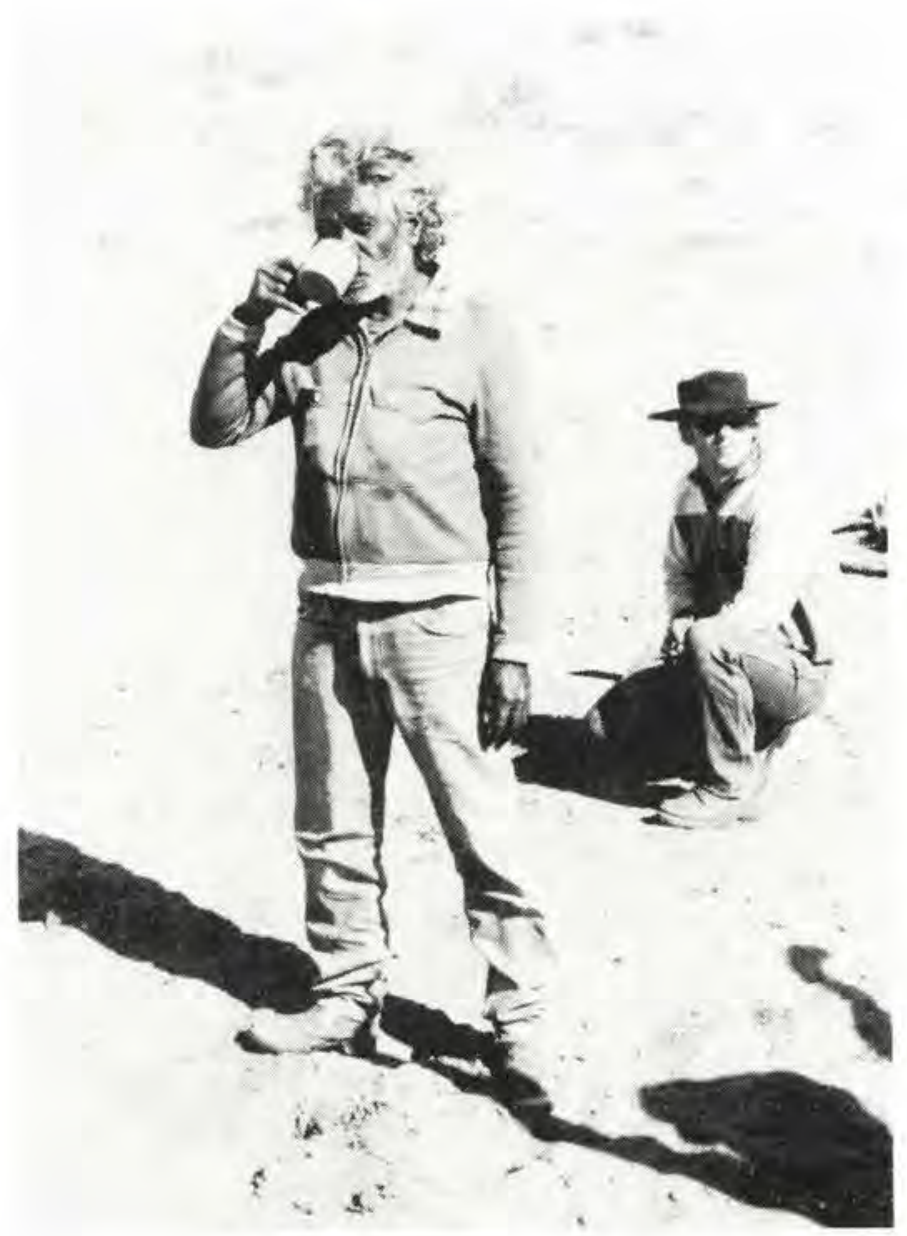

Plate 1: The late Sydney Stuart is the first to have a drink from the Murraburt soak, where his grandfather had lived. Peter Clark is in the background recovering from digging with a handauger. Photo by J. Knight

Peter Clark and I were able to visit these nine soaks in May 1983. ${ }^{1}$ It was a unique experience to see the places which I had heard about for many years from Wangkangurru people, and to find exact confirmation of what they had spoken and sung about. For instance there is a deep trench at the Pirlakaya soak, there are white rocks on the sandhill just north of Pilpa.

1 A brief account of this trip, with strong emphasis on the use of four wheel drive vehicles, appeared in the Overlander, August 1983 (pp.30-37). It was written by Tony Love. 


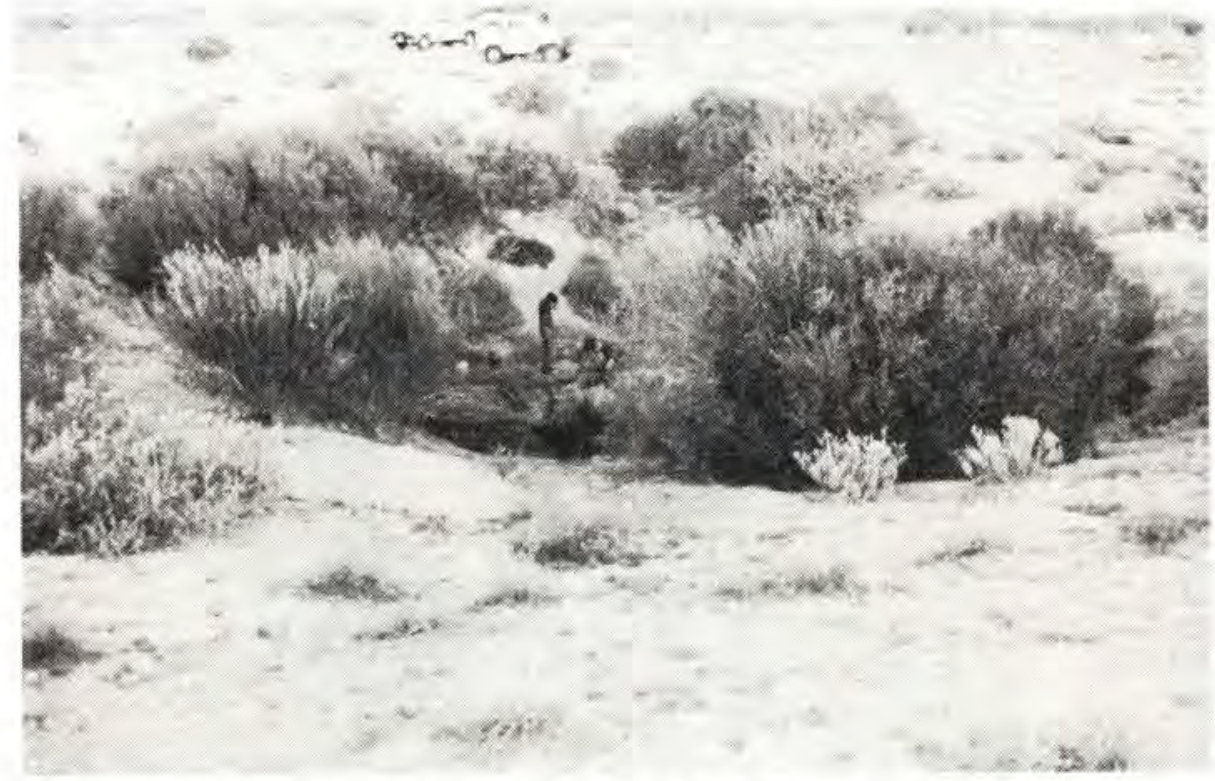

Plate 2: At the Pudlowinna soak. Dennis Bartell and Tony Love are using the hand-auger.

Photo by J. Knight

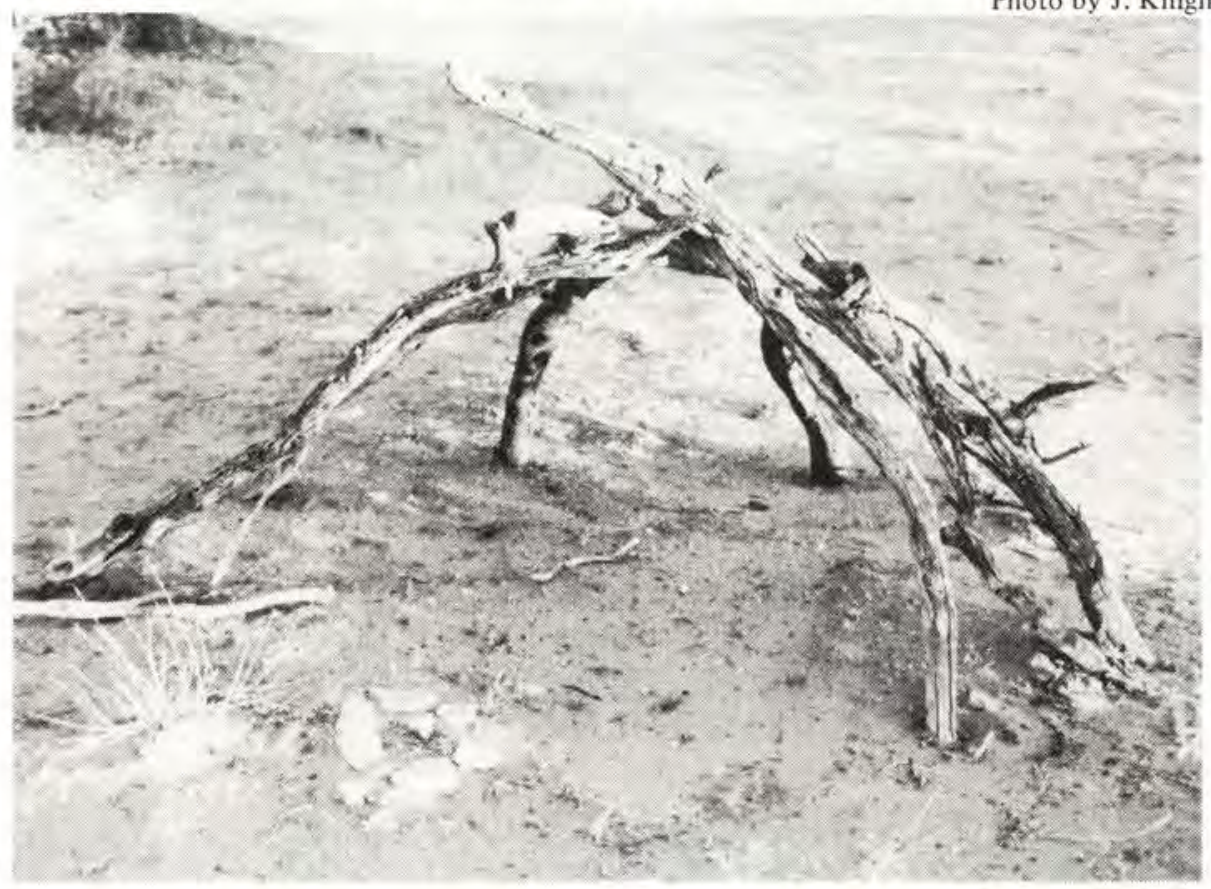

Plate 3: The remains of a humpy at Parlani soak.

Photo by J. Knight 


\section{LEAVING THE SIMPSON DESERT}

Beelpa soak. The soaks are all different from one another, they have their own special character, but in some ways they are all similar: they are shallow depressions in low-lying areas. Wangkangurru people got down to the water by digging narrow tunnels, in some cases over $20 \mathrm{ft}$ deep. There were more of these soaks than the nine visited by Lindsay, at least sixteen that we know of, with water of varying quality. After rains people could move away from the soaks and get water from the many irpi 'claypans' and ikara 'swamps'. There are accounts of people digging deep channels in the claypans so that water would stay there longer to delay the necessity of having to go back to the soaks. One of the traditional song cycles of Wangkangurru literature deals with the theme of the poor taste of the water of one of the soaks, Pulupudnunha (Lindsay's 'Boolaburtinna' soak) and people longed for rain so that they could go out to the swamps, but the soaks were always there when all the surface water had dried out: there was no reason to leave the desert.

There can be no doubt about it, Wangkangurru people lived and died in the desert: the artefacts around the mikiri and the burial sites bear witness to that. ${ }^{2}$ They had matrimonial and ceremonial links with lower Southern Aranda people, and trade-links much further afield still: there are accounts of Wangkangurru people going to Anna Creek to get grinding dishes, and to Parachilna in the Flinders Ranges to coliect red ochre. This meant that groups of Wangkangurru men visited their neighbours (as did other Aboriginal people) and went on long expeditions, but their home was, and remained, the Simpson Desert. In the summer of 1899-1900, however, lured by tales of plenty, they left the Simpson desert never to return.

By 1965 there were only three Wangkangurru people left who were born in the desert. They were:

Maudie Naylon Akawilika, born about 1885 , probably at Marrapardi, the Murraburt soak. She died in Birdsville in 1981.

Mick McLean Irinjili, born about 1888 at Pirlakaya, the Beelaka soak. He died at Pt Augusta in 1977. His immense store of traditional knowledge made him a legend in his own lifetime.

Topsy McLean Ikiwiljika, born in about 1898 at Puluwani, the Poolowanna soak, called Pudlowinna by Lindsay. Topsy, who was Mick McLean's sister, was only a small child when she left, and had to be carried. She only had second-hand knowledge about the desert, from her parents and other relatives. She died in 1974.

Both Mick McLean and Maudie Naylon were in 'the mikiri country' long enough to regard it as their home and they constantly spoke of it, particularly Mick. The late Graham Hercus and I, and later Bob Ellis (from the Aboriginal Heritage Unit of South Australia) made several attempts to take Mick McLean back to his country, but he was old and ill, and convinced that he would die there, which he very nearly did.

Mick McLean was a brilliant speaker of Southern Aranda as well as Wangkangurru and worked with T.G.H. Strehlow. He naturally wanted to talk about the desert. In his famous 1970 article on 'Totemic Landscape' T.G.H. Strehlow appears to have misunderstood Mick McLean when he used Wangkangurru terms: this is probably one of the very few minor errors he ever made. ikara ('jikara') is the Wangkangurru word for 'swamp'. Strehlow thought it meant 'freshwater lake', and then listed under that name most of the Simpson Desert

2 We found burial sites in the immediate vicinity of several of the mikiri. See Peter Clarke (MS). 
soaks. He wrote (p.93):

'Erenjeli had been given the names of the larger freshwater lakes by his male relatives, who had left this area only about the turn of the century'.

In the note referring to this passage (p.135) he listed Pulawini, Marabati, Murkarana, Kalijikana, Jatalkna, Palkuru, Palarinuna, Pirbana, Pilakaija, Kalalumba, Parapara, Walbarka, Puruputu, Palani, Madluna.

These places were soaks: this is corroborated by the evidence of the last desert Wangkangurru people, by Lindsay's description, and by all the evidence we gathered on our visit. There was nothing secret-sacred about either the names or the actual soaks, nothing that belonged only to the 'male relatives'. Everybody had to know the names, everybody had to live at the soaks when the surface water dried out. There were long song cycles and myths centred on the soaks. All these myths had secret-sacred sections, but by sheer necessity the soaks themselves had to be common property. Maudie Naylon knew the names and the places and the greater part of the myths just as well as did Mick McLean.

There were secret-sacred places in the Simpson desert, but they were not soaks: apart from several outcrops of gypsum these were claypans, such as for instance MaRarru, the Two Men (Initiation History) ritual centre. Men went there for ceremonies when conditions were suitable. Some women had to be present too, but only on the periphery: they certainly could not visit this site casually when foraging.

In conversations with Mick McLean we usually somehow ended up speaking about 'the mikiri country'. In August 1970, he gave a detailed account of how his people left the desert. This account is in Wangkangurru with a few sentences in English, and it is transcribed here in a practical orthography, and with a grammatical gloss: details of the orthography and of the abbreviations used in the gloss are listed at the end of this paper. Some minor changes have been made to the sequence of the story as told by Mick McLean, particularly where we had some interruptions. 
Text

1 M.thangka-libarna arni Stay -ANC we (excl)

Palkuru- nga.

anthunha apirla,

My cousin $^{4}$, aunt of child

katha-nangka-ngura $\quad$ Riley $^{5}$-kunha kaku

walk -CONT S - CONT Riley -of elder sister

katjiwiRi Anpanuwa, ukakunha apayi.

big Anpanuwa, her younger brother.

2 uka anthunha withiwa anthunha apirla-pula

He my male cousin my cousin-two

Palkuru-nga mingka mirpa-rna, mingka

Balcoora-LOC hole dig out-IMP, hole

\section{Translation}

$1 \mathrm{M}$.We were all living at Balcoora. $^{3}$ There was my female cross-cousin, older than me ${ }^{4}$ daughter of my father's sister, and there were Riley's ${ }^{5}$ big sister Anpanuwa and her younger brother.

2 This male cross cousin of mine and the two girl cousins older than me, we all used to dig holes in the loose

*M. refers to Mick McLean. As the whole text is from him the abbreviation is not repeated except where there are a few questions from L. (Luise Hercus).

3 The Balcoora soak is within the Simpson Desert Conservation Park. Lindsay (MS: p.4) describes his visit there in 1886 as follows:

$\therefore$. top of sandhill at 6.50 - met 5 natives who were friends of our boy - they said water was only a "pickaninny way" travelled on until 8 oclock being tired of the natives "one fellow sandhill then catch him water".

Camped on a good flat - no spinifex today.

Saturday 9 th. Unable to get an observation for Latitude. Thermometer $48^{\circ}$ at 5.15 a.m. On bearing 45 at 6.45 over a sandhill and at 6.55 came to the well ... . The well is on the slope of a depression, not in the centre as is the case with the others, it is $20 \mathrm{ft}$ deep and sloping. Some large native Miamias are here'.

Subsequently (p.6) he mentions:

'We had brought another native with us from Balcoora, our boy not being very sure about finding these later wells', [he is referring to soaks in the eastern part of the Simpson desert].

4 apirla. The basic meaning of this kinship term is 'unmarriageable woman of the opposite moiety and of one's own or the alternate generation level'. The shade of meaning intended here is 'older female crosscousin', and it may refer to Maudie Naylon Akawilijika: according to her own account she spent some of her earlier years at the same camp with Mick McLean, and they both jokingly recalled how she could boss him about because she was a big girl while he was only little. She however probably left earlier and was not part of the group that finally left from Balcoora. The term apirla is given as 'abila' by Elkin (1938:64). It corresponds to the Adnjamathanha word ngaparla, (for the loss of initial $n g$ see Hercus 1979 and for details about ngaparla see Schebeck, Hercus and White 1973). Interestingly enough the geographically intervening language, Arabana, uses the less closely related term pilja.

5 Anpanuwa was the second oldest of the Naylon family. She had several brothers; the brother who was close in age to Mick McLean was probably Jimmy Naylon Arpilintika, who died in Birdsville in about 1965. His brother Riley Naylon was considerably younger: he was born after the departure from the Simpson Desert. He was a brilliant stockman and horse-breaker (see the illustration 'Riley rides the skewbald colt' in Farwell 1950 p.32). He died in Port Augusta in 1978. 
2 (continued)

mirpa-rna pudnu-ruku kutha yatjapara dig out -IMP, heap - ALL water sparrow ${ }^{6}$

pirda-lhuku kutha pirpa-lhuku kutha kill -PURP water-pour-HIST water

kudni-lhiku puthu-ru, mingka kuthaput -HIST dish- INST, hole water-

marna-li - ma -lhuku.

mouth-ADV-make-HIST.

3 irlina yatjapara mapu thika-rna, partjarna

Thus sparrow mob come-IMP, all

wila-wila thika-rna mapa - rna -yi

multitude come-IMP assemble- -IMP -ACT

-thika-lhuku, kutha thurre puntha-lhuku

-come-HIST, water inside drink -PURP

kutha-nga mapa -rnda.

water-LOC assemble -PRES.

4 pula-ru nhatji-nangka-rda mingka, might be Two-ERG watch-CONT S -PRES hole,

murlapara ${ }^{7}$ too! pularu wilpilpumu

pigeon Two-Erg branches

punta-yi-kanha, brush'm in.

break-ACT-PERF,

5 uta kari-nha pirda-lhuku partjarna

Then they-ACC kill -HIST all

mingka-nga. kathi ngurku, njari-njara, kathi

hole- LOC. Meat good, tiny, meat

mardu, thiki-lhiku, wadni-lhiku.

sweet, take-HIST, cook -HIST.
2 (continued)

ground (by the soak) so that

we could kill 'sparrows'.

We used to pour out water that we got from a wooden dish and put the water into the hole, we filled the hole right up to the rim.

3 Then a mob of 'sparrows' would come, a huge number would get together to come there. They would flock together to drink the water inside the hole.

4 Two of us would be watching that hole all the time, there might even be a topknot pigeon! ${ }^{7}$ We used to break off branches and brush the birds into the hole.

5 Then we killed them all in the hole. That was good meat, only a tiny amount on each, but it was sweet. We would take them back (to our humpy) and cook them.

6 yatjapara was the Arabana-Wangkangurru name for the orange chat, Ephthianura aurifrons. It seems that chats were widely called 'sparrow' in the Lake Eyre basin. Gason 1879:286 mentions a Diyari term for 'sparrow', and Johnston 1943:286 considers that the name 'sparrow' refers to the closely related gibber bird or desert chat Ashbyia lovensis, but this does not occur in Arabana country and yatjapara certainly does. Although they can exist in a very arid environment all the chats are easily attracted to water. Two important mound-springs in Arabana are called Yatjaparanha on account of this. It was usually considered pathetically small as a food item, and this feature is emphasised in several legends, most notably in the Emu History from Mierantana Waterhole on the Macumba, where a grandson feeds his blind grandfather on yatjapara 'sparrows', while he himself has lovely feasts of emu down-wind from where the old man is sitting.

7 muriapara is the top-knot pigeon which was considered a much more desirable item of food than 'sparrows'. 
6 L. thutirla thadlu, karna padni?

Boy only, man not?

M. karna katji-nangka-ngura, karna wila-wila,

Man turn-CONT SCONT, men multitude, uljurla kari yuka-ka pawa-ku pawa woman they go -PAST seed-DAT seed '

karra-rna ikara-nga, thirthi-pawa. seek -IMP swamp-LOC, pigface -seed.

7 thutirla mankarra-kari thangka-ngura kutha-nga, Boy girl -they sit -CONT water-LOC, anthunha withiwa katjiwiRi, arluwa my male cousin big, child

katjiwiRi karuwali kathi-nga katha-ngura big youth meat-LOC walk -CONT pirda-lhuku, yatjapara tharni-rna -thu. kill -PURP, sparrow eat -IMP -EMPH.

8 thutirla-ru -thu pantu -nga warra-rna. Boy -ERG-EMPH salt lake -LOC play -IMP.

L. kultii? round stone?

M. No. mathapurda katjiwiRi irlina warra-rnda No. Old man big thus play -PRES kultji-ri. $^{8}$ stone-INST.

9 uta thangka-lhuku walta nguru-nga walta Now sit -HIST time other -LOC time nguru-nga. malka ngurka-rina week malka other -LOC. Not know -DIST week not ngurka-rina month malka ngurka-rina year, know -DIST month not know -DIST year, malka ngurka-rina irlangkuta not know -DIST thus

how long we been there,

ngarka nguru ngarka nguru thangka-rda. evening other evening other stay -PRES.
6 L. Was it only the boys who did this, not the men? M. The men were out, walking about, there were many, many men (at Balcoora). The women went out searching for grass seed in the swamps, and especial. ly the seed of pigweed (Aizoon quadrifidum, common on the edges of claypans as well as dunes).

7 We boys and girls sat by the soak. But my older crosscousin, he was a big boy, a youth. He was walking about killing meat while we were eating 'sparrows'.

8 We boys played on the saltlake.

L. (That game called) 'round stone'?

M. Only the big grown-up men played that game.

9 We stayed at Balcoora time and time again.

We knew nothing of weeks, or months, or years; we had no idea of how long we had been there. We just stayed there one night after another.

8 kultii means 'round stone' and the term was also used for the game which was played with such a (Footnote 8 continued on next page) 
10 madli-ngaru ngurka-rna, madli-ngaru kanjakarla Cold -way know -IMP, cold -way heat nguyu-nga thangka-rda wadnangkani pirda-yi one -LOC stay -PRES carpet-snake ${ }^{9}$ kill -ACT -ngura anthunha anja-ru, kathi idni-ngura, -CONT my father-ERG, meat lay-CONT, yardu thangka-lhuku. satisfied stay -HIST.

not worrying about food, not like today, eat every five minutes!

yardu -thu thangka-rda, arlali... satisfied-EMPH stay -PRES, in the end...

11 L mikiri tharti witji $-k a$ ?

Soak dry become-PAST?

M No! kutha katjiwiRi thangka-ngura, nguRa

No water big stay -CONT, camp

wila-wila-ru kutha nguyu puntha-rna multitude-ABL water one drink -IMP

mikiri-nganha, nguRa katjiwiRi thangka-ngura. soak -from, camp big stay -CONT.

12 Marrapardi-nga nguRa katjiwiRi thangka-ngura, Murraburt-LOC camp big stay -CONT,

Murkari-nga nguRa katjiwiRi Padlaringu-nga. Mokari ${ }^{10}$-LOC camp big Padlaringu-LOC.

That's not far from Kallakoopah, we come through there afterwards, when we were getting ready to leave that country.
10. We did know the cold of winter-time and the heat of summer. We all lived there together and my father went about killing carpet-snakes ${ }^{9}$ : we had meat and were satisfied. We weren't really worrying about food, not like today when people eat every five minutes!

In the end ...

11 L. The soak dried out?

M.No, we had plenty of water. There were a lot of humpies there and we all got water from the soak, we had a big camp there.

12 There was a big camp at Murraburt (the westernmost Simpson soak). There was also a camp at Mokari ${ }^{10}$ and a big camp at Padlarina. That's not far from the Kallakoopah. We came through there afterwards, when we were getting ready to leave that country.

(Footnote 8 continued)

stone. Mick McLean always stressed that the game was like cricket. It was played in large flat areas such as claypans by grown men as light entertainment after special ceremonial occasions, particularly initiation. There is a song-sequence about the game in the Two Men Initiation History.

9 Carpet-snakes were a much sought after item of food throughout the Lake Eyre basin, but they were hard to catch. Men risked their lives digging for them in the sandhills: they dug out the burrows of carpet-snakes and the resulting tunnel could easily cave in

10 Mokari is in the western Simpson desert. It is not one of the main soaks: it is known as a Dog History site. The name Mokari is now used for a well developed air-strip used in oil exploration in the Macuriba lease area of the Simpson desert. 
13 L. minha-ku mikini thadna-ka?

What -DAT soak (country) leave -PAST?

M. anaku. kari yanhi-lhiku arni yuka-rnda I don't know. They say -HIST we go -PRES

kudnangkari karla-ruku ngarrimatha-nga south creek-ALL flood -LOC

thangka-lhuku.

stay -PURP.

14 kutha karla-nga kira-ngura, karla-nga

water creek-LOC flow-CONT, creek-LOC

thangka-lhuku parru tharni-lhiku.

stay -PURP bream eat -PURP.

kari yanhi-lamintja-rnda thadna-rnda nguRa

They talk -RECIP -PRES leave -PRES camp

arla.

true.

15 yuka-rnda Punarani -riku. waljpala

Go -PRES Poonarunna ${ }^{11}$-ALL. Whitefellow

thangka-ngura, out-station kari thangka-liparna, stay -CONT, they stay -ANC,

but I didn't know that then.

16 My father had seen whitefellows, but my mother and I hadn't. I was a boy then leave me along

Palkuru. He came up for that red ochre over there at Parachilna.

Parachilna-ruku kari yuka-ngura anha -ALL they go -CONT me

thadna-rna thutirla njara, arni nguRa-nga leave -IMP boy small, we EXCL camp -LOC thangka-ngura.

stay -CONT.
13 L. Why did you leave the mikiri country?

M.I don't know. They (the adults) started saying: 'We'll go down south to the creek and stay there by the flood. waters'.

14 'There is water flowing in the creek, we can stay by the creek and eat boney bream'. They talked like this amongst themselves and so they left their own country.

15 They were going to Poonarunna. ${ }^{11}$ There were whitefellows there, living on an out-station, but I didn't know that then.

16 My father had seen whitefellows, but my mother and I hadn't. I was only a little boy when he left me at Baicoora to go and get red ochre from over there at Parachilna.

They went off to Parachilna, leaving me behind as a small boy. We went on staying in our camp (at Balcoora).

11 The Poonarunna out-station was in use for only a short while, it was already abandoned at the time of Gregory's visit in 1901. When Mick McLean first arrived there it was still inhabited: this dates the events described by Mick McLean in this paper as taking place in 1899-1900. This date coincides with drought conditions over much of southern and central Australia, and good rains in parts of Queensland, which caused floods in the Diamantina and the Kallakoopah which is simply a branch of the Diamantina. 
16 (continued)

The end of that railway was along Beltana ${ }^{12}$ in that time, waru yarndi.

long, long ago.

17 He made a song out of that, my old man, Wangkangurru song:

$$
\begin{aligned}
& \text { v.1. Railway yarilu' waya' } \\
& \text { tralaa tralaa } \\
& \text { Beltana yarilu' waya' } \\
& \text { tralaa tralaa } \\
& \text { yarilu' waya' Beltana yarilu' } \\
& \text { tralaa tralaa Beltana tralaa. } \\
& \text { warritha-ru thupu nhatji-rna: } \\
& \text { afar -ABL smoke watch -IMP: } \\
& \text { v.2. kali'ngkrima kayiya' } \\
& \text { kali'ngkrima na' kali'ngkrima yayai' } \\
& \text { wandura warritha' } \\
& \text { far away } \\
& \text { wandurali'ya }
\end{aligned}
$$

That is all song word for maka-thupu wanka-ngura.

$$
\text { fire -smoke rise -CONT. }
$$

18 walta nguru-nga antha katjiwiRi-thin -ina train Time other-LOC I big -become

nhanhi-lhiku, maka-thupu tharka-ngura, train see -PURP, fire -smoke stand -CONT, train maka-thi-ya! maka-thupu nhanhi-lhiku fire -EMPH! fire -smoke see -PURP waya-rnda. wish-PRES.

I did see'm in the end, when I went to Peake, Warrina.
16 (continued)

The railway line ended at Beltana ${ }^{12}$ at that time, long, long ago in the past.

17 He made a song out of that (journey), my old man, a Wangkangurru song:

v.1.

The railway tralaa tralaa, Beltana tralaa tralaa, tralaa, tralaa, Beltana tralaa.

$\mathrm{He}$ could see the smoke from afar:

v. 2 .

Smoke rising'

Smoke rising from afar.

Smoke rising.

These are all song words (not ordinary Wangkangurru) for 'smoke rising up from a fire'.
18 Later, as I was growing up, I wanted to see a train. I wanted to see the smoke going up in a continuous column, oh how I wanted to see the fire of a train! I wanted to see the smoke of that fire!

I did see it in the end, when I went to Peake Station, at Warrina (the siding used by people from Peake, see J.W. Gregory 1906:140).

12 This statement involves a chronological problem. At the time of the exodus from the Simpson desert Mick was about 12 years old, and there are other pieces of evidence which confirm that he was born about 1888. The railway line ended at Beltana in 1881, it was continued to the north after that, reaching Marree in January 1884 (Fuller 1975), so Mick McLean's father Pintha-Mirri must have been to Parachilna before Mick was born. It seems likely that Mick telescoped into one the two or more visits to Parachilna that he had heard about as a child. Obviously - and Mick's account makes this very clear - the men who had been on the long and adventurous journey talked and sang about it for years. (For discussions about journeys for red ochre see Gason 1879:280, Horne and Aiston 1924:128, and Elkin 1934:5). 
19 anthunha anja, not proper anja but belonging to My father, father

Finke, he call'm cousin my anja, kari nguyu-nga father, they one -LOC

yuka-ka, uka-ru malaru pantu malaru go -PAST he -ERG however salt lake however $\begin{array}{llll}\text { kari-nangka-ngura, pantu } & \text { katjiwiRi } & \text { kathi } \\ \text { see-CONT S-CONT, salt lake } & \text { big } & \text { Lake }\end{array}$ Thandra.

Eyre.

' 20 He got a song there too that same time:

Kathi-Thanda' warda'yi yadle 'yi ya Kathi-Thanda' Lake Eyre over there close Lake Eyre wamara wamara pantjina 'nga te'yi ya Kathi Thanda' Wind wind circle round Lake Eyre warde'yi warde'yi ya Kathi-Thanda' yala'. there there Lake Eyre.

21 My uncle Tjangili, he find this song.

Tjarlpa Parkulu Kinpili. uka-kunha arluwa nguyu, Trees Two Kinpili. He-POS child one, mankarra, girl,

while we at Palkuru,

katha-nina puthu-nga go -DIST dish -LOC.

22 uka thangka-liparna, muyu nguru muyu ngure He stay -ANC, day other day other thangka-rda stay .PRES

I might as well give you Kanti-pumunha:

Kanti pulpa'ra ya'ra rapinta'nayi wadlhu 'kanha pulpa- ra marnda, waranga? Ground him powder-CAUS make, where?

This is Tjangili's song, he made it on the way back from Parachilna.
19 My father, not my real father but a man belonging to the Finke, who called my father 'cousin' - they all went together (down to Parachilna), he however was fascinated by the salt lake, that vast salt lake called Lake Eyre.
20 So he got a song for Lake Eyre on that same occasion, (the journey to Parachilna):

Lake Eyre is just there close by, Lake Eyre.

The whirlwind circles around, it circles around Lake Eyre.

Lake Eyre is just there close by, Lake Eyre.

21 My uncle Tjangili, he found this song (i.e. it came to him as an inspiration).

The song called The Two Trees was found by Kinpili. He (Tjangili) had only one child, a (baby) girl, and while we were at Balcoora they carried her about in a wooden dish.

22 He stayed on, day after day he stayed.

I might as well give you his song about the waddy (which he had lost).

My waddy can smash the ground to powder, My waddy, where is it?

This is Tjangili's song. He composed that too on the way back from Parachilna. 
23 mikiri-nga ngardu thanga-rnda ikara-nga, Soak -LOC nardoo remain-PRES swamp-LOC, widla, pilta, parkilja madli-ngaru. pear, pigface, parakeelya winter-way.

kanjakarla-nga kari katha-yi-ngura wadla-ra Heat -LOC they walk-ACT-CONT hunger-CAUS thangka-ngura warditji-nganha thuruthurda stay -CONT mulga -from mulga apple

ardakarla tharni-lhiku.

mulga gall eat -HIST.

24 ngardi-kira. wadlhu kari thadna-ka karla-ruku dry root. country they leave -PAST creek-ALL ngaritji-lhiku. go down-PURP.

\section{Marna-wiljpa nhanhi-lhiku;} Mouth-Open ${ }^{13}$ see -PURP?

M.uka-kunha-ruku wadlhu-ruku yuka-lhuku, He -POS -ALL country-ALL go -PURP, uka-ru kanti-ngura. he -ERG call -CONT.

25 kurdawiRi kari thangka-ngura katjiwiRi wild parsnip they stay -CONT big pudnu-pudnu-nga ngarrimatha-ru kari-nha loose soil -LOC flood -ERG they-ACC walji-la -yi- ngura. karla-nga kira-nha-nga. water-ALT-ACT-CONT. creek-LOC flow-NP-LOC.

26 That karla been not like this other time we went there.

kalka-walta athu' nha iki -nha ngunta-lhuku Some-time I you ACC take-NP show -PURP kari-nha wadlhu. they-ACC country.

karla wadlhu-ru nhampa-ka. creek soil -ERG bury -PAST.
23 Near the soak there was always nardoo in the swamps, native pear (Cynanchum floribundum), and also pigface and parakeelya in the wintertime. In the heat of summer they still foraged to satisfy our hunger and we ate mulga-apples, mulga gall.

24 The roots of trees were dry when they left that country to go down to the creek.

L. Was it to see old man Marna-Wiljpa?

M.It was to go to his country, he was calling for us.

25 There was a big lot of wild parsnip (Trachymene glaucifolia) growing on the loose soil, watered by the flood. The creek was flowing.

26 That creek was not like this the time we went there (in August 1969). Some time I'll take you to show you their country, but the creek has been buried and filled in with soil.

13 At the turn of the century the ritual leader of the Fish and Crane History was Marna-Wiljpa an old man of the Wangkatjari group of Wangkangurru who lived in the Marlupapu country along the Kallakoopah and the Diamantina. The name Marna-Wiljpa means 'Mouth Open' and refers to the Ancestral Cod. 
27 kari arlali, arni yuka-rna, arlarda witji -rna They finally, we go -IMP, ready become-IMP kudnangkari yuka-lhuku. yuka-lhuku kutha south go -PURP. Go -HIST water kari-ri wanpa -rda yunga-ru kadnungka they-ERG carry -PRES bag-INST hare wallaby patha-nga, mudluwaltu patha-nga kutha skin -LOC, rat-kangaroo skin -LOC water iki- lhiku, mikiri-nganha kutha ngurku, madli. take-PURP, soak -from water good, cool.

You don't want to drink all the time.

28 kutha madli idni-nha-nga yakutha-nga, yunga water cold lie -NP -LOC bag -LOC, water-bag -nga arni kilta-rna yunga puthu-nga -LOC we pull -PRES water-bag dish -LOC

idni-ya -nga uljurla kari-ri wanpa-ngura lie -PTC-LOC woman they-ERG carry-CONT kari-kunha kutha, ngampa padni yuka-ka. they-POS water, nardoo stone nothing go -PAST.

29 Topsy puthi-nga anthunha ama -ru iki-rna, Topsy dish -LOC my mother-ERG take-IMP, antha malaru thutirla yuka-rnda warra-rna. I however boy go -PRES run -IMP. My uncle there two, two anthunha anja njara-pula, my father small-two, one finished along Finniss, one at Macumba.

30 yuka-lhuku thangka-yiwa-lhuku Pulawani -nga 14 Go -HIST sit -TR -HIST Pudlowinna-LOC kudnangkari thangka-yiwa-lhuku muyu parkulu. south sit -TR -HIST day two. Pulawani -ri kudnangkari, kutha kalpa-lhuku Pudlowinna-ABL south water get -PURP yarda Pulawani thangka-lhuku. again Pudlowinna sit -HIST.
27 They finally set out, they got ready to travel south. They went carrying water in waterbags made of harewallaby (Lagorchestes) skin and rat-kangaroo (Caloprymnus) skin. They took water from the soak (at Balcoora). It was good, cool water.

You don't want to drink all the time.

28 There was cold water in the bags, the waterbags, and we pulled out the waterbags to pour water into a wooden dish. The women carried the water for everybody, they went without the (heavy) nardoo-stones.

29 My mother carried Topsy in a wooden dish. I was a boy and went running along. My two younger fathers (my father's two younger brothers) were there too. One died at Finniss Springs, the other at Macumba.

30 We started walking and on our way we stopped at the Pudlowinna $^{14}$ soak to the south (of Balcoora). We stayed there for two days before leaving. We headed south from Pudlowinna, but then we came back and stopped again at Pudlowinna to get more water.

14 Pudlowinna is Lindsay's version of the name of the soak north of the big saltlake named Poolowanna on modern maps. It is not very far from Balcoora to Pudlowinna.

(Footnote 14 continued on next page) 
31 kadnhini kumpira witji -rna kadnhini Grandmother dead become-IMP grandmother

Urlirda-nganha uljurla katjiwiRi yarndi, Urlirda-from woman big (old) ancient, apirla.

paternal grandmother.

nhampa-rda kanhangarda 'kanha Irlipaltja-nga' 15 bury -PRES there her Irlipaltja-LOC

\section{kaRu kudnangkari}

there south

between Pulawani and Padlaringunha.

32 uljurla yarndi padni yuka-rna, kanhangarda Woman ancient not go -IMP, there muthu pudluka uljurla iranja witji -ninaru, padni like bullock woman skinny become-PLUP, not panpa-ma-lhuku parda, uka wantja-rda, parda move-SP-PURP weak, she die -PRES, weak wapayi-ma-ki; finish -IMP-EMPH;

Just like old cow, ${ }^{16}$ can't walk no more.
31 My grandmother died, my grandmother from Urlirda (an important Southern Aranda site of uncertain location on the lower Finke). She was my paternal grandmother, the grandmother of the opposite moiety, an old, very old woman. They buried her at Irlipaltja, away to the south, between Pudlowinna and Padlaringu.

32 That poor old woman just couldn't walk any further, she was there just like a bullock (that has been overrun). She had become quite emaciated and was so weak that she could not move. She was so weak that she died there. Just like an old cow $^{16}$ she just couldn't walk any further.

(Footnote 14 continued)

Lindsay gives the following account (MS:p.11):

'This was a good well with a good supply but some dead thing must have got into the water as it was absolutely rotten and made us sick'.

He also speaks of a 'magnificent flat'.

Pudlowinna is indeed situated in a well vegetated low-lying area. The immediate surrounds of the soak were surprisingly green at the time of our visit to the area in 1983 and on a subsequent occasion in 1984. This was the only soak at which we saw reasonably preserved wooden artefacts, a shield and a spear.

15 Irlipaltia is not a soak. It is probably the name of a particularly big sandhill: sandhills of major size or significance all had distinct names in Wangkangurru country.

16 Disrespect was the last thing Mick McLean would have intended by this expression. He loved his paternal grandmother and moreover she represented his main link with the southern Aranda country around the lower Finke. He was simply evoking a pathetic picture, one that he must have witnessed many times while mustering.

On another occasion Mick McLean described to Sally White and me how his father had actually carried the sick woman on that trip over the sandhills for several days until she died. 
33 L. kari muyu kulpari thangka-ngura? They day three sit -CONT?

M.anthunha apirla -nga? ko, muyu my paternal grandmother-LOC? Yes, day

kulpari thangka-ngura, ukaliri yuka-lhuku arlarda three sit -CONT, then go -PURP ready

witji -rna kudnangkari yuka-lhuku

become-IMP south go -HIST

(Padlaringu-ruku) kudnangkari yuka-lhuku, (Padlaringu-ALL) south go -HIST,

going south all the time.

34 L. minha tharni-ka?

What eat -PAST?

M.Plenty kathi, thalka, yadluru, kadnungka. meat, bilby, lesser bilby, hare wallaby.

L. pawa padni?

Flour nothing?

M.pawa njurdu, wanpa-nguru kardapu-nga.

Flour too, carry -CONT head -LOC.

L. ngalta -nga?

Headband-LOC?

M. wirinja-nga. wirinja karra-rna kardapu-nga

Nest -LOC. Nest tie -IMP head -LOC

kudni-lhiku ngalta -nga wanpa-lhuku pawa put -HIST headband-LOC carry -HIST flour ipa -yiwa-lhuku, irlana-thu mudlu -nga, grind -TR -PURP, Thus -EMPH sandhill -LOC, parra-lhuku mudlu -nga. travel-HIST sandhill-LOC.

tjarlpa wadni-wa-lhuku, nguRa marra-nga

Food cook-TR-HIST, camp new -LOC

kurda-yiwa-lhuku.

sleep -TR -HIST.
33 L. And did they stay there for three days?

M.For my paternal grandmother? Yes. We sat there for three days and then we got ready to travel south to Padlaringu, and then we went south again, travelling south all the time.

34 L. What did you eat?

M. There was plenty of meat, there were bilbies (Macrotis lagotis), lesser bilbies (Macrotis leucura), and hare wallabies (Lagorchestes leporoides).

L. Didn't you have any grass seed?

M. We had grass seed too, they used to carry it on their heads.

L. On top of the headband?

M. In a 'nest'. They tied up this nest and put it on their heads on the headband. They carried grass. seed so that they could grind flour. This is how they travelled on the sandhills, over sandhill after sandhill. They cooked food on their journey, and they slept in a different camp every night. 
35 uta, wanga-wanga yuka-lhuku wanka-lhuku-thu Then, early morning go -HIST rise -HIST-EMPH mathapurda:

old man:

'nhayi Thikira, wurru, wurru-kunha mudlu 'Here Thikira, Crane, Crane-POS sandhill wantarnda katjiwiRi, kaRu thadna-rna.' steep(?) big, there leave -IMP'.

Karla-kupa nhanhangarda

Creek-small (the Kallakoopah) there

katji-rna-ya-rna kudnangkari thika -lhuku turn-IMP-TR-IMP south return-HIST

kudnangkari witji -lhiku.

south become-HIST.

36 Soakage there, main soakage call'm Pawa-mingka, flour-hole,

karla-nga, mudlu nhararda thangka-ngura creek-LOC, sandhill there sit CONT big high sandhill might be flat now, I don't know, those big high sandhills we been talking about ${ }^{17}$

wabmara-ru partjarna thawi-ka. wind -ERG all throw-PAST.

37 nhararda uka wantarndara ularaka-nga kadnha There this steep(?) History-LOC stone nhanhanga... there...

L. When did you first see other mob?

M. nhanhanga karla-nga katjiwiRi-nga There creek-LOC big -LOC nothing on the way. thangka-ngura kaRu. sit -CONT there.
35 Then early one morning as we were walking and going up (a sandhill) the old man said:

'This sandhill here is called Thikira. It (represents) the Ancestral Crane, it belongs to the Ancestral Crane. It is a high and steep sandhill. This is where the Crane left (the creek country).' 'It is here that the Kallakoopah, 'the Small Creek' (as opposed to the Diamantina, the Big Creek) bends and turns straight south, it goes south altogether then.'

36 There is a soakage here, a main soakage that is called Pawa-mingka 'Grass seed Hole'. It is right in the creek, and there is a big sandhill just above.

That high sandhill might be flat now, I don't know, like those big high sandhills we were talking about. ${ }^{17}$

The wind might have blown them away altogether.

37 There (on this steep sandhill?) is this stone from the History Time ...

L. When did you first see another mob of people?

M.Over there on the Big Creek, the Diamantina.

There was nothing, nobody on the way. They were living on the Diamantina.

17 The sandhills in question were on the western side of the Simpson desert in the area around Tuppana waterhole on the lower Macumba. Mick McLean had an uncanny memory for places; he led us to the remains of a cattle-rustler's yard on the lower Diamantina about seventy years after he had last visited that area. Near Tuppana however the sandhills had been eroded and changed so much that even he very nearly got lost. 
37 (continued)

Pirlakayanha is further east, most from that country already gone karla-nga thangka-ngura, Marree, creek-LOC sit -CONT,

Killalpannina.

38 arni yuka-ka

We go -PAST

we're not the last, last people my uncle

kaka Imatuwa, kaka arla anthunha, ukakunha uncle Imatuwa, uncle true mine, his

ama kari nhata, nhata kari yuka-rna mother they behind, behind they go -PRES

arni-nha wampa-rna-rnda, uta ipali

us -ACC chase -SP-PRES, already before $y u k a-k a$.

go -PAST. ${ }^{18}$

39 arni yuka-rna kutha paka-rna-yangu iltjiltji We go -PRES water dig -SP -PLUP soakage anthunha anja -ru kutha ngunta-ka: my father-ERG water show-PAST:

nhararda kutha iltjiltjayi!! uta paka-lhuku! Here water soakage!! Now dig -PURP!

40 kathi pirda-lhuku yuka-ngura mudlu-nga meat kill -HIST go -CONT sandhill-LOC mudluwaltu ngadla wadnangkani, kapirri, kadni rat-kangaroo many carpet-snake, goanna, frillneck yadla pirda-yi -ngura close kill -ACT-CONT

old men kill'm, mob old men, Riley's father, ${ }^{19}$ kama partjama wapayi-ka kari anthunha mapu man all finish -PAST they my mob anthunha wathili mapu, partjarna wapayi-ka. my own mob, all finish -PAST.
37 (continued)

Beelaka is further east (than Balcoora). Most of the people from that country had already gone. They were living by the Diamantina, at Marree and at Killalpannina.

38 We went on. We were not the last people, the last were (those with) my uncle, my proper uncle Imatuwa. He came back for his mother and those with her. They came behind, they were behind us. $\mathrm{He}$ was chasing people (out of the desert), he had already left before, but came back. ${ }^{18}$

39 We went digging a soakage for water, my father showed us.

'Here is soakage water!! Now dig!'

40 They went to kill meat on the sandhill, they got ratkangaroos (Caloprymnus) and many carpet snakes, goannas and frillneck lizards. They got them quite close by. A mob of old men killed them, Riley's father, ${ }^{19}$ and all those old men who are now dead, my mob, my own mob. They are all dead now.

18 Mick McLean recalled on another occasion how Imatuwa had left the desert earlier with a group of people from Beelaka, and how he returned to collect all his relatives.

19 Riley Naylon's father Ngunili was a ritual leader of the grass-seed history. 
41 You know where you been

pathara nhanhi-lhiku kadni ularaka-nganha ${ }^{20}$ box-tree see -HIST frillneck History-from

kadnha -nga that's where my cousin kumpira mountain -LOC

dead

\section{Thirili}

Thirili

all come with my mob.

42 kurda-yiwa-lhuku Makaru-thakanili.

Camp-TR -HIST 'Fire by-striking' (Wild Dog Hole).

(Punarani -nga) pudluka wila-wila, manaputu.

(Poonarunna-LOC) bullock multitude, don't know.

antili nhanhi-lhiku nhantu, pudluka.

First time see -HIST horse, bullock.

43 mikiri-nga malka thangka-ka rapiti: thalka, Desert-LOC not sit -PAST rabbit: ${ }^{21}$ bilby, mudluwaltu, yadluru, parkaya, kadnungka rat-kangaroo, lesser bilby, bettong, hare wallby njurdu thangka-ngura Pampilta -nga also sit -CONT Pompapillinna-LOC

kadnungka thangka-ngura mudlu -nga. hare wallaby sit -CONT sandhill-LOC.

44 kari-ri nguni-ri anha damper tharni-lhiku, They-ERG give-NAR me damper eat -PURP, malka tharni-lhi, madla, pawa athu ngurka-yira not eat -HAB, bad, seed I know -PUNC tharni-ra 'thu. eat -PUNC I.
41 You know the box trees you were looking at, by the stony hill belonging to the Frillneck Lizard History? ${ }^{20}$ That is where my cousin Thirili died. $\mathrm{He}$ and all those (others now dead) came with my mob.

42 On our way we camped at Makaru-thakanili 'Wild Dog Hole'. (Further on at Poona. runna) there was a great multitude of bullocks. They were new to me. That was the first time I ever saw a horse or a bullock.

43 There were no rabbits ${ }^{21}$ in in the desert: we had bilbies, rat-kangaroos, lesser bilbies, bettongs and hare-wallabies. At Lake Pompapillina too there were hare-wallabies on the sandhill.

44 They gave me damper to eat but I would not eat that stuff, it was no good. I only knew grass-seed flour and that is what I ate.

20 The reference here is to an increase site for frillneck lizards and for witchetty grubs. Box-bark had been used in the ritual and we were looking at the trees from which bark had been stripped long ago. The site is in Arabana country near Mt Coppertop in the Peake and Denison Ranges.

21 The soaks in the Simpson desert are surrounded by large deposits of fragments of bones of animals, birds and lizards that had all been cooked and eaten there. The mammal remains were of bettongs and other small marsupials, there was no sign of rabbit remains. The only exception was at Murraburt, the westernmost soak, and we surmised that people must have revisited this soak, coming from Dalhousie at a later period. (Peter Clarke, MS). 


\section{LINGUISTIC EFFECTS OF THE MOVE FROM THE DESERT.}

The people who lived in the Simpson Desert following the life-style described above by Mick McLean called themselves Wangkangurru mikiri-nganha 'Wangkangurru people from the soaks' (the name Wangkangurru is based on wangka 'speech', ngurnu 'strong, hard'). They also called themselves Wangkangumu Mungathirri-nganha 'Wangkangurru from the high sandhill country'. These terms were used to distinguish them from the Wangkangumu karlanganha, the Wangkangurru from the Creek (i.e. the Diamantina and the Kallakoopah). The people 'from the Creek' also called themselves Marlupapu-nganha 'from the Marlupapu country', as well as Wangka-tjaka and Wangka-tjari 'little language'.

Wangkangurru people obviously had an advantage over some of the other groups in the northeast of South Australia: the Yawarawarka for instance were fenced out of their own lands, poisoned food was put out for them and they were hunted down. They had to seek refuge at the mission at Killalpannina (see Farwell 1950:160). Wangkangurru people left their country of their own volition, over a prolonged period, and the exodus described by Mick McLean was the second-last of what was presumably a number of similar events. Wangkangurru people, both 'from the Creek' and 'from the high sandhills' went to a number of different destinations as is evident from the testimony of the people themselves and from all the written sources, particularly Horne and Aiston (1924) and Basedow (MS). They went not only to the mission at Killalpannina but also to Birdsville, to the stations at Andrewilla, Alton Downs, Pandie Pandie, Mt Gason, and Mundowdna, to Marree, Finniss Springs, Anna Creek, Peake, Oodnadatta, Macumba and Dalhousie. The population became completely fragmented although to this day the descendants of Wangkangurru people are aware of their original unity.

The Wangkangurru 'from the high sandhills' were divided into a number of local groups but they spoke one language. This was still evident in the 1960s: the speech of the people born in the Simpson desert showed no more than the ordinary variation one finds between individuals. One or two younger persons who had been brought up by parents who both came from the desert, and people who spent their early years in a similar environment all spoke in the mikiri way, down to small details of intonation and emphasis. There are now only two people left, two sisters at Birdsville who speak what one might call the pure Simpson desert form of Wangkangurru. Other people of Wangkangurru descent at Birdsville were brought up among speakers of Yarluyandi, Mithaka and Ngurlupurlu. Their speech is still Wangkangurru, but with a few differences particularly in intonation and emphasis, some minor points of grammar and the use of particles (see Hercus MS). Their singing style is also different: Mick McLean was always intrigued by his friend and distant relative Johnnie Reese, who was born on Alton Downs, singing Wangkangurru songs 'other people's way'. Similarly the descendants of Wangkangurru people who were living far away to the west among speakers of the closely related Arabana language tended to have an Arabana accent and were influenced to varying degrees by Arabana grammar. Two people were said to be 'mixed up' and this indeed seemed to be the case. Another person spoke with a Diyari accent. In 1965 there remained only two Wangka-tjari speakers, whose ancestors had come from the Kallakoopah, and had belonged to the Karla-nganha or Marlupapu-nganha group. They had spent some time at Killalpannina and knew Diyari well but did not speak with a Diyari accent.

Anyone who has heard the people who were born in the Simpson desert cannot but have been impressed by their strong sense of unity, the sense of 'my own mob' which encompassed 
the local groups using the different soaks. This unity was reflected in the language. But by now, over eighty years since the 'Wangkangurru of the high sandhills' left their homes in the Simpson Desert this exodus has had its full effect and there are almost as many variants of Wangkangurru as there are speakers. It seems inevitable that in years to come this fragmentation of the language will continue. Already now members of the younger generation, even siblings, vary considerably as to what and how much, sadly in fact if anything, they have learnt of the Wangkangurru language mikiri-nganha 'from the soaks', Mungathirri-nganha 'from the high sandhills'.

\section{ORTHOGRAPHY}

A practical orthography has been used in this paper.

Plosives have been written as unvoiced, i.e. $k, t, t h, p$, except for the retroflex which has been written as $r d$, since it is always voiced in Wangkangurru.

The prestopped nasals and laterals (which are not phonemic) have been written as they are pronounced, as $d n h, d n, p m, d l h, d l$.

Retroflex consonants have been indicated by an $r: r d, r n, r l$.

Interdental consonants have been indicated by $h: d h, n h, l h$.

Palatal consonants have been indicated by $j: t j, n j, l j$.

In the case of prestopped consonants and homorganic consonant clusters, retroflex, dental and palatal consonants have been indicated only once, by $\mathrm{r}, \mathrm{h}$, and $\mathrm{j}$ respectively, $r n d$, not $r n r d ; d n h$ not $d h n h$; $n t j$, not nitj.

The three r-sounds of Wangkangurru are represented as follows:

$r$ is a front flap

$r r$ is a front trill

$R$ is retroflex

\section{ABBREVIATIONS}

The following abbreviations have been used for linguistic terms in the interlinear gloss:

$\begin{array}{llll}\text { ABL } & \text { Ablative case } & \text { HIST } & \text { historical past } \\ \text { ACC } & \text { accusative case } & \text { IMP } & \text { imperfective } \\ \text { ACT } & \text { active stem-forming suffix } & \text { LOC } & \text { locative case } \\ \text { ADV } & \text { adverbial suffix } & \text { NAR } & \text { narrative past } \\ \text { ALL } & \text { allative case } & \text { PAST } & \text { past tense } \\ \text { ANC } & \text { ancient past } & \text { PERF } & \text { perfect } \\ \text { CAUS } & \text { causative case } & \text { PLUP } & \text { pluperfect } \\ \text { CONT } & \text { continuous participle } & \text { POS } & \text { possessive suffix } \\ \text { CONT S } & \text { continuous stem-forming suffix } & \text { PRES } & \text { present tense } \\ \text { DIST } & \text { aspect showing distance in time or space } & \text { PUNC } & \text { punctiliar present } \\ \text { EMPH } & \text { emphatic clitic } & \text { PURP } & \text { purposive } \\ \text { ERG } & \text { ergative case } & \text { SP } & \text { speed form, indicating action undertaken } \\ \text { EXCL } & \text { exclusive pronoun } & & \text { before departing } \\ \text { HAB } & \text { habitual aspect } & \text { TR } & \text { transitory aspect }\end{array}$




\section{LEAVING THE SIMPSON DESERT}

\section{BIBLIOGRAPHY}

Austin, Peter. A grammar of Diyari, South Australia. Cambridge, 1981.

Basedow, Herbert. Report upon the Third Medical Relief Expedition among the Aborigines of South Australia. (Archives Department, Public Library of South Australia), MS.

Clark.,Peter. Notes on sites in the Simpson Desert. MS.

Elkin, Adolphus P. 'Cult Totemism and Mythology in Northern South Australia' Oceania 5(2), 1934: 171-190.

'Kinship in South Australia' Oceania 8(4), 1938:419-452.

Farwell, George. Land of mirage. The story of men, cattle and camels on the Birdsville Track. Adelaide, 1950.

Fuller, Basil. The Ghan. Adelaide, 1975.

Gason, Samuel. 'The Manners and Customs of the Dieyerie Tribe of Australian Aborigines', in J.D. Woods, The native tribes of South Australia. Adelaide, 1879:258-306.

Gregory, John W. The Dead Heart of Australia. London, 1906.

Hercus Luise A. 'How we danced the Mudlunga', Aboriginal History 4, 1977:5-31. 'Mick McLean Irinjili [obituary]', Australian Institute of Aboriginal Studies, Newsletter, n.s. (7), 1977:27-28.

'In the Margins of an Arabana Wanganuru Dictionary: The loss of Initial Consonants', Australian Linguistic Studies, Pacific Linguistics C-54, Canberra, 1979:621-651.

'Language convergence in the Birdsville area'. (Paper contributed to ANZAAS, Dunedin 1983). MS.

Horne, George A. and Aiston, George. Savage Life in Central Australia. London, 1924.

Johnston, T.H. 'Aboriginal Names and Utilisation of the Fauna in the Eyrean Region', Transactions of the Royal Society of South Australia, 56, 1943:244-311.

Lindsay, D. Journey from Dalhousie to the Queensland Border in January 1886. (Archives Department, Public Library of South Australia), MS.

Litchfield, Lois. Marree and the tracks beyond in black and white, commemorating the Centenary of Marree, 1883-1983. Adelaide, 1983.

Love, Tony. 'Desert Rats, a tough road test plus the secret life of the Simpson Desert', Overlander, August 1983:30-37, 74-5.

Schebeck, Bernhard; L.A. Hercus and I.M. White. Papers in Australian Linguistics no.6. Pacific Linguistics, A-36, Canberra, 1973.

Strehlow, T.G.H. 'Geography and the Totemic Landscape in Central Australia: a functional study' in Berndt, Ronald M. Australian Aboriginal Anthropology. Nedlands, W.A., 1970:92-140. 